\title{
Polychlorinated dibenzo-p-dioxins, dibenzofurans and biphenyls in fish from the Netherlands: concentrations, profiles and comparison with DR CALUX ${ }^{\circledR}$ bioassay results
}

\author{
S. P. J. van Leeuwen • P. E. G. Leonards • W. A. Traag • \\ L. A. P. Hoogenboom • J. de Boer
}

Received: 8 March 2007 /Revised: 4 May 2007 / Accepted: 8 May 2007 / Published online: 13 June 2007

(C) Springer-Verlag 2007

\begin{abstract}
Fish from Dutch markets were analysed for concentrations of polychlorinated dibenzo-p-dioxins/dibenzofurans $(\mathrm{PCDD} / \mathrm{Fs})$ and dioxin-like polychlorinated biphenyls (DLPCBs) and compared with the new European maximum residue levels (MRLs), set in 2006. In a first study on 11 different fish and shellfish from various locations, concentrations of $\mathrm{PCDD} / \mathrm{Fs}$ were nearly all below the MRL for $\mathrm{PCDD} / \mathrm{Fs}$ [4 pg toxic equivalents (TEQ) per gram wet weight (ww)] and nearly all below 8 pg total TEQ/g ww, the new MRL for the sum of PCDD/Fs and DL-PCBs. Some samples exceeded the total TEQ MRL, such as anchovy, tuna and sea bass. Furthermore, 20 (out of 39) wild eel samples exceeded the specific MRL for eel (12 pg total TEQ/g ww), as the study revealed PCDD/F TEQ levels of 0.2-7.9 pg TEQ/g ww and total TEQ values of 0.9 to $52 \mathrm{pg} / \mathrm{g}$ ww. TEQ levels in farmed and imported eel were lower and complied with the MRLs. Smoking eel, a popular tradition in the Netherlands, only had marginal effects on PCDD/F and DL-PCB concentrations. Owing to volatilization, concentrations of lowerchlorinated PCBs were reduced to below the limit of quantification after smoking. DL-PCBs contributed $61-97 \%$ to the total TEQ in all eel samples. This also holds for other fish and shellfish (except shrimps): DL-PCB contributed (on
\end{abstract}

Electronic supplementary material The online version of this article (doi:10.1007/s00216-007-1352-6) contains supplementary material, which is available to authorized users.

S. P. J. van Leeuwen $(\varangle)$ • P. E. G. Leonards · J. de Boer Institute for Environmental Studies, VU University,

De Boelelaan 1087,

1081 HV Amsterdam, The Netherlands

e-mail: stefan.van.leeuwen@ivm.falw.vu.nl

W. A. Traag • L. A. P. Hoogenboom

RIKILT - Institute of Food Safety,

P.O. Box 230, 6700 AE Wageningen, The Netherlands average) from 53 (herring) to $83 \%$ (tuna) to the total TEQ. Principal-component analysis revealed distinctive congener profiles for PCDD/Fs and non-ortho PCBs for mussels, pikeperch, herring and various Mediterranean fish. The application of new TCDD toxic equivalency factors (TEFs) set by the World Health Organization in 2006 (to replace the 1997 TEFs) resulted in lower TEQ values, mainly owing to a decreased mono-ortho PCB contribution. This decrease is most pronounced for eel, owing to the relative high monoortho PCB concentrations in eel. Consequently, a larger number of samples would comply with the MRLs when the new TEFs are applied. The DR CALUX ${ }^{\circledR}$ assay may be used for screening total TEQ levels in eel, in combination with gas chromatography-high resolution mass spectrometry confirmation of suspected samples. An almost 1:1 correlation was found when the 1997 TEFs were applied, but, surprisingly, a 1.4-fold overestimation occurred with application of the 2006 TEFs.

Keywords Dioxins $\cdot$ PCBs $\cdot$ Fish $\cdot$ Eel .

Consumption $\cdot$ DR CALUX ${ }^{\circledR}$

\section{Introduction}

Following the Belgium dioxin crisis in 1999, polychlorinated dibenzo- $p$-dioxins/dibenzofurans (PCDD/Fs) and dioxin-like polychlorinated biphenyls (DL-PCBs) in food have received considerable attention from the European Commission (EC), leading to new maximum residue levels (MRLs) for various food items. For fish, an MRL of 4 pg toxic equivalents (TEQ) per gram wet weight (ww), expressed as equivalents of 2,3,7,8-tetrachlorodibenzo- $p$-dioxin (2,3,7,8-TCDD; toxic equivalents, or TEQ) was set in July 2002, temporarily excluding the contribution of the DL-PCBs [1]. In 2006, a 
new MRL for the sum of PCDD/Fs and DL-PCBs was set at $8 \mathrm{pg} \mathrm{TEQ} / \mathrm{g} w w$, and a specific one for eel (12 g TEQ/g) [2]. $\mathrm{PCDD} / \mathrm{Fs}$ and DL-PCBs are persistent compounds that are ubiquitous in the aquatic environment. Compared with other food items, fish can bioaccumulate considerable amounts of these contaminants [3]. The presence of PCDD/Fs and DLPCBs in regularly consumed fish or in fish originating from point sources has been demonstrated [4-8]. The Dutch rivers Meuse, Rhine, Waal and IJssel are highly polluted with PCBs and dioxins owing to a high degree of urbanization and industrialization along these rivers in the Netherlands, Germany, France and Belgium. Total TEQ (sum of PCDD/F and DL-PCB) values in marine and freshwater fish fillets from 1991 ranged from 0.8 to $22 \mathrm{pg}$ TEQ/g ww for cod and eel, respectively, and up to $504 \mathrm{pg} \mathrm{TEQ} / \mathrm{g}$ ww for fish livers have been reported [9]. In order to determine the current contamination of Dutch edible fish and shellfish, two studies were undertaken. The specific aims of these studies were:

1. To determine PCDD/F and PCB concentrations in popular fish from the Dutch market and to evaluate the compliance with current EC legislation. Because of its popularity in the Netherlands and its high lipid content, eel was studied in more detail in a separate study.

2. To determine a possible removal of contaminants by smoking of eel.

3. To evaluate the $\mathrm{PCDD} / \mathrm{F}$ and $\mathrm{PCB}$ profiles in the fish samples.

4. To evaluate the increase or decrease of TEQ concentrations as a result of application of the new WHO toxic equivalency factors (TEFs) from 2006 ( $\mathrm{TEF}_{\mathrm{WHO}}$ 2006) versus the 1997 TEFs $\left(\mathrm{TEF}_{\mathrm{WHO}} 1997\right)$.

5. To evaluate the suitability of the DR CALUX ${ }^{\circledR}$ bioassay [10] for screening eel samples in combination with gas chromatography-high resolution mass spectrometry (GC-HRMS).

6. To evaluate the risk for human consumption of highly contaminated eel samples.

\section{Materials and methods}

Sampling and sample preparation

\section{Fish survey}

Fish samples were purchased in 1999 and 2000 from fishermen and commercial traders. The set of samples included coalfish and cod (liver) from the North Sea, eel from IJsselmeer, herring from the North Sea and the English Channel, mackerel from the Celtic Sea, Skagerrak and the
Atlantic Ocean, mussels from the Dutch Wadden Sea and the Eastern Scheldt, pike perch from various Dutch freshwater locations, farmed salmon from Scotland and Norway, shrimps from Norway and the Dutch coast and tuna from the Mediterranean and Sri Lanka. In addition, a limited number of fish samples were purchased in 2003 and 2004 in order to monitor contaminant concentrations over time. The complete list of fish samples can be found in the electronic supplementary material.

\section{Eel study}

The wild eel (yellow eel Anguilla anguilla) survey included eel from 39 freshwater locations originating from main river systems (e.g. Meuse, Rhine, IJsselmeer), small rivers, canals and lakes. The eels were caught in May and June 2001 by using electrical fishing equipment. Eels hibernate in the Netherlands in the sediments during the winter season and cannot be caught between November and April. May and June are therefore the best months for sampling. Later in the season, some eels build up higher lipid contents and start to migrate to sea to begin their journey to the Sargasso Sea [11]. Although those 'silver eels' can be distinguished by their grey colour, in contrast with the regular 'yellow eel', mistakes in this identification can be made [12]. Farmed eel were purchased from 11 Dutch eel farmers. Fourteen samples of imported eel were purchased from different commercial traders (three wild eel and 11 farmed eel samples). The influence of smoking on the contaminant concentrations in eel was determined by smoking two batches of farmed eel, either traditionally $(n=3)$ or industrially $(n=1)$ and analysing the raw material and the smoked material.

For both studies, pooled samples were prepared for the fish and shellfish samples. All fish and shellfish samples were market-size. Lengths and weights of each individual fish were recorded. For all fish, pooled samples were prepared from equal amounts of fillets of 25 individuals per location or origin. For the pooled mussel samples, approximately $5 \mathrm{~kg}$ of mussels was cooked for $5 \mathrm{~min}$, the shells were removed and the meat $(1 \mathrm{~kg})$ was collected. Concerning shrimps, approximately $1 \mathrm{~kg}$ was cooked for 5 min and peeled. All pooled fish and shellfish samples were homogenized using a Waring blender and stored in glass jars at $-20{ }^{\circ} \mathrm{C}$ until analysis.

Analytical procedure

\section{$P C D D / F s$ and $D L-P C B S$}

The complete WHO set of 17 PCDD/Fs and 12 DL-PCBs [13] were analysed in all fish samples. The lipid fraction, including the indicator PCBs, DL-PCBs and PCDD/Fs in 
the survey study, was extracted by chloroform/methanol according to a modified method of Bligh and Dyer [14]. In the eel study the lipids were extracted for $12 \mathrm{~h}$ by Soxhlet extraction with a dichloromethane/ $n$-pentane mixture (1:1 v/v) (picograde, LGC Promochem, Wesel, Germany). The solvent was evaporated from the extracts and the remaining concentrates were sent to RIKILT (Wageningen, The Netherlands) for analysis by GC-HRMS of PCDD/Fs and DLPCBs. Concentrations of dioxins, non-ortho and mono-ortho PCB were determined by GC-HRMS, according to the method of Tuinstra et al. [15]. Separation between the target compounds and fat was carried out using gel permeation chromatography (GPC). The system consisted of a highperformance liquid chromatography pump (Gilson, model 305), an autosampler (Gilson, model 231) equipped to inject $12.5 \mathrm{ml}$, and a fraction collector (Gilson, model 202) adapted to collect $300-\mathrm{ml}$ fractions in $500-\mathrm{ml}$ glass flasks. The glass GPC column (Spectrum, $62.5 \mathrm{~cm}$ ) was packed with Biobeads SX 3. An additional clean-up was performed with activated $\mathrm{Al}_{2} \mathrm{O}_{3}$ in an automatic sample preparation system using solid phase extraction columns (ASPEC, Gilson). The columns were packed with $1.0 \mathrm{~g}$ deactivated $\mathrm{Al}_{2} \mathrm{O}_{3}$ (7\% water) shortly before use. The separation between planar (dioxin-like) and nonplanar compounds (di-ortho PCBs) was carried out with porous graphitized carbon (Hypercarb 1006, 4.6 mm, Shandon, Runcorn, UK). The contents of column were successively eluted with cyclohexane/dichloromethane $(1: 1 \mathrm{v} / \mathrm{v})$ and toluene, both at a flow rate of $2 \mathrm{ml} / \mathrm{min}$. This resulted in one fraction with monoortho and di-ortho PCBs. The second fraction contained PCDD/Fs and non-ortho PCBs. The final extracts were concentrated to $10 \mu \mathrm{l}$ and analysed by GC-HRMS (Autospec, Micromass, operated at 10,000 resolution), equipped with a DB-5-MS capillary column (60 m, 0.25-mm inner diameter, $0.25-\mu \mathrm{m}$ film thickness). The mass spectrometry method to determine the tetra-octa dioxins is based on US Environmental Protection Agency protocol 1613.

\section{Indicator PCBS}

The indicator PCBs (IUPAC nos. 28, 52, 101, 118, 138, 153 and 180) [16] were Soxhlet-extracted for $6 \mathrm{~h}$ with dichloromethane $/ n$-hexane $(1: 1, \mathrm{v} / \mathrm{v})$ (picograde, LGC Promochem, Wesel, Germany) [14]. The lipids were removed by $\mathrm{Al}_{2} \mathrm{O}_{3}$ column chromatography $(20 \times 2-\mathrm{cm}$ inner diameter, $15 \mathrm{~g}$ deactivated $\mathrm{Al}_{2} \mathrm{O}_{3}$ ). After concentration, the eluate was further cleaned using silica column chromatography on a 40 $\mathrm{cm} \times 6$ - $\mathrm{mm}$ inner diameter glass column, containing $1.8 \mathrm{~g}$ $\mathrm{SiO}_{2}$ Kieselgel (Merck, Darmstadt, Germany). After treatment with concentrated sulfuric acid (95-98\%, Merck, Darmstadt, Germany) the first fractions of $10 \mathrm{ml}$ iso-octane were analysed using a Hewlett-Packard HP-6890 gas chromatograph, equipped with splitless injection $\left(250{ }^{\circ} \mathrm{C}\right)$ and electron capture detection $\left(300{ }^{\circ} \mathrm{C}\right)$, and a CP-Sil8 capillary column $(50 \mathrm{~m}, 0.15-\mathrm{mm}$ inner diameter, $0.30-\mu \mathrm{m}$ film thickness). The standards used were, whenever possible, more than $99 \%$ pure and certified and were obtained from Promochem (Wesel, Germany), Ultra Scientific [14], Cambridge Isotope Laboratories (Andover, USA), BCR (Brussels, Belgium) and TNO (The Netherlands).

\section{Lipid content}

The fat contents of all fish samples except eel were determined using an adapted method of Bligh and Dyer [14], whereas for eel, in which the contribution of phospholipids is negligible, the total fat content was determined gravimetrically from the Soxhlet extract as described earlier.

\section{DR CALUX ${ }^{\circledR}$ screening}

In the eel study, the total TEQ levels in eel were also estimated by the DR CALUX ${ }^{\circledR}$ assay. Samples of $0.25 \mathrm{~g}$ fish oil (kindly supplied by Nutreco, Boxmeer, The Netherlands) were purified on columns containing $10 \mathrm{~g}$ acid silica $(33 \%$ $\mathrm{H}_{2} \mathrm{SO}_{4}$ ), as described by Bovee et al. [17]. Before total evaporation of the hexane/diethyl ether extract in a SpeedVac, $100 \mu \mathrm{l}$ dimethyl sulfoxide (DMSO) was added as a keeper. An aliquot of $20 \mu \mathrm{l}$ was added to $2 \mathrm{ml}$ incubation medium and $250 \mu \mathrm{l}$ was added in triplicate to three different wells of a 48-well plate containing p-GudLuc 1.1-transfected H4IIE cells. After $24 \mathrm{~h}$, the medium was aspirated, the cells were washed and lysed and an aliquot was used for determining the luciferase response in a Luminoskan (Labsystems). Total TEQ in the oil was estimated from a calibration curve, prepared from cleaned fish oil samples spiked with the $17 \mathrm{PCDD} / \mathrm{Fs}$, three non-ortho PCBs (nos. 77, 126 and 169) and two mono-ortho PCBs (nos. 118 and $156)$ at $30,60,120$ and $203 \mathrm{pg} \mathrm{TEQ} / \mathrm{g}$ oil, as confirmed by GC-HRMS (relative contribution to TEQ 15, 40 and 45\%). These samples were included in each analytical series. The concentration in the fat was subsequently converted to a wet weight concentration based on the amount of fat.

\section{Quality assurance}

The analysis of the PCDD/Fs and (DL-)PCBs is accredited according to ISO 17025 . The quality of the analysis was ensured routinely by including blanks, duplicate samples, recovery experiments and the analysis of internal reference materials in each series of samples. Furthermore, certified reference materials were analysed frequently, and both laboratories participate in the proficiency testing schemes of QUASIMEME [18] and Folkehelsa [19]. The DR CALUX $^{\circledR}$ method was used in several interlaboratory studies, such as in the EU DIFFERENCE project [20-22]. 


\section{Calculations and statistical evaluation}

The TEQ calculations are based on the WHO TEF values from 1997 [13]. In the first fish study, the DL-PCBs included the non-ortho-substituted PCBs 77, 126 and 169 and the mono-ortho-substituted PCBs 105, 118 and 156. For an eel sample from the river Rhine it was calculated that when using this limited set of DL-PCBs and the $\mathrm{TEF}_{\mathrm{WHO}} 1997$, an underestimation of $11 \%$ was found for the mono-ortho PCBs but no significant underestimation or overestimation was seen for the non-ortho PCBs. This somewhat affected the total TEQ ( $6 \%$ underestimation). For other fish, this effect will be smaller because the mono-ortho PCB contribution to the total TEQ is smaller (see "Effect of smoking of eel on contaminant concentrations"). In the eel study, all DL-PCBs were included, i.e. the non-ortho PCBs 77, 81, 126 and 169 and the mono-ortho PCBs 105, 114, 118, 123, 156, 157, 167 and 189. All TEQ concentration values are reported according to the lower-bound principle, which means that individual congeners below the detection limit or nonquantifiable peaks due to interferences were not taken into account in the calculation of the TEQ concentrations. In "Evaluation of new TEFs", a comparison is made between the results calculated with either the $\mathrm{TEF}_{\mathrm{WHO}} 1997$ values or in the 2006 revised TEF values [23].

\section{Results and discussion}

Fish survey

\section{Polychlorinated dibenzo-p-dioxins/dibenzofurans}

The results presented in Table 1 show that PCDD/PCDF TEQ values in all samples were below the European MRL of $4 \mathrm{pg}$ TEQ/g ww [1]. Median PCDD/F TEQs in other species like herring, salmon, pike perch and mussel were intermediate between those for the highly contaminated eel and the low concentrations found in cod, coalfish, mackerel, tuna and shrimp (where concentrations were below 1 pg TEQ/g ww). Concentrations in individual samples can be found in the electronic supplementary material.

For comparison of our results with those obtained in other European regions, a selection of concentration data from other studies are shown in Table 2. In some other studies, different TEF systems were used [9, 26-28]. These TEFs are listed in the electronic supplementary material. The median concentrations reported here are very similar to those reported in Dutch fish from 1991 [9], although the use of a different TEF system in that study (from a Dutch working group, DWG) led to an underestimation of about $10 \%$ for the PCDD/F TEQ as compared with the $\mathrm{TEF}_{\mathrm{WHO}} 1997$ (data not shown). The lower TEF of 1,2,3,7,8-pentachlorodibenzo- $p$ - dioxin (1,2,3,7,8-PeCDD; 0.5 instead of the TEF $\mathrm{WHO}_{1997}$ of $1.0)$ accounted primarily for this difference. The PCDD/F TEQ concentrations in mussels, shrimps, mackerel and cod are in the same range as those found in northwest European fish, but are higher than the levels reported for the Mediterranean fish (Table 2). Levels in herring in this study were much lower than those reported for the Bothnian Sea and Grenland fjord. The latter location was highly polluted by PCDD/Fs from historical industrial activity. A study on the correlation of age and size of herring versus PCDD/F TEQ concentrations in herring from the Bothnian Sea revealed that concentrations in herring over 4 years of age exceeded the EC MRL for PCDD/F TEQ [24]. Consequently, that herring would not be suitable for consumption, whereas herring from a similar size in the Netherlands still comply with the EU MRL. PCDD/F TEQ levels in salmon from the 2000 study were higher than those from 2004. The 2004 samples agreed nicely with the levels observed in other studies [24, 25].

\section{Dioxin-like PCBs}

Median DL-PCB TEQ concentrations showed a wide variation (Table 1). Median concentrations in herring, tuna, mackerel, mussels, pikeperch and salmon were intermediate, whereas median concentrations in cod, coalfish and shrimps were below 1 pg TEQ/g ww. DL-PCB TEQ. Concentrations in Dutch fish from 1991 were considerably higher for mussels, shrimps and mackerel [9]. This is partly explained by the different TEFs used in that study (DWG TEFs, see electronic supplementary material) which led to an overestimation of the PCB TEQ of $10-40 \%$ in the 1991 study, depending on the species and origin (data not shown). Furthermore, a steep decrease of PCB contamination in Dutch river systems was observed from the late 1970s to the present [30]. DL-PCB TEQ concentrations in cod and pikeperch were in the same range in the present (Table 1) and past (Table 2) Dutch studies.

\section{Eel study}

\section{Polychlorinated dibenzo-p-dioxins/dibenzofurans}

A second study was initiated entirely focusing on eel from Dutch markets. As regards the freshwater locations, emphasis was placed on sampling of eel from polluted areas, but imported and farmed eel were included as well. The PCDD/F TEQ concentrations in eel from different freshwater locations ranged from 0.2 to $7.9 \mathrm{pg} / \mathrm{g}$ ww (Table 3, see electronic supplementary material for concentrations in the individual samples). The highest PCDD/F TEQ concentrations were found in IJsselmeer and the main rivers Meuse and Rhine and their respective deltas in the western part of the Netherlands. PCDD/F TEQ values in six out of 39 (15\%) eel samples were 


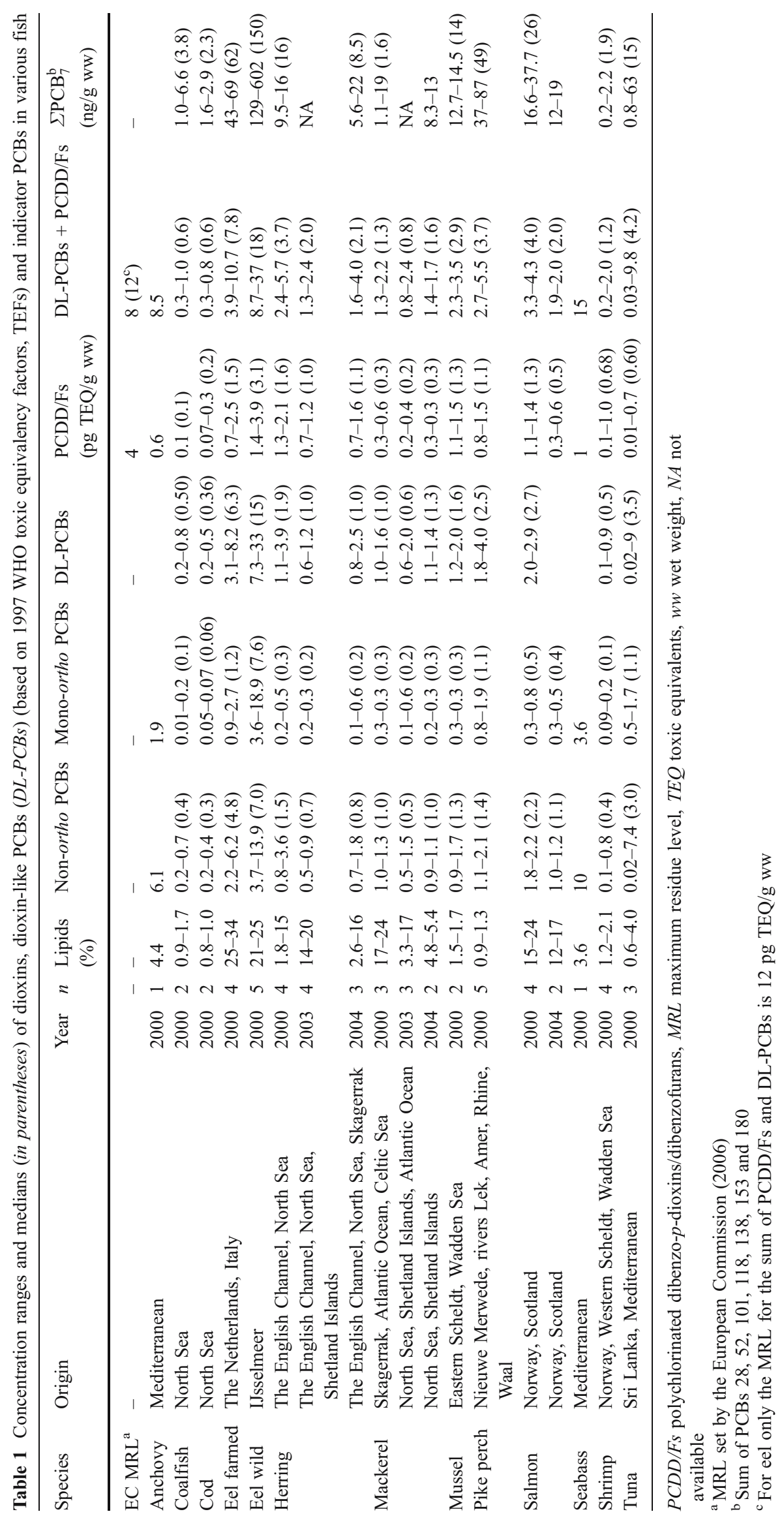


Table 2 Selection of literature data on concentrations of PCDD/Fs and DL-PCBs (pg TEQ/g ww) in edible fish and shellfish from various European origins

\begin{tabular}{|c|c|c|c|c|c|c|c|}
\hline Species & Origin & Year & $\mathrm{TEFs}^{\mathrm{a}}$ & DL-PCBs & $\mathrm{PCDD} / \mathrm{Fs}$ & $\mathrm{DL}-\mathrm{PCBs}+\mathrm{PCDD} / \mathrm{Fs}$ & Reference \\
\hline Eel & Freshwater, Netherlands & 1991 & DWG & $1.7-19$ & $0.32-4.2$ & $2.0-22$ & [9] \\
\hline Pikeperch & & & & 2.6 & 0.79 & 3.4 & \\
\hline Herring & North Sea, Shetland Islands & & & $1.5-4.4$ & $0.84-1.9$ & $2.3-6.3$ & \\
\hline Mackerel & & & & $3.7-4.2$ & $0.66-0.77$ & $4.4-5.0$ & \\
\hline Shrimp/mussel & & & & $1.7-4.4$ & $0.93-1.9$ & $2.6-6.3$ & \\
\hline Cod/sole & & & & $0.66-2.0$ & $0.14-0.77$ & $0.8-2.0$ & \\
\hline Herring & Bothnian Sea & & WHO-98 & $1.3-10$ & $2.5-25$ & $3.8-35$ & {$[24]$} \\
\hline Herring & Northern Europe & 1995-1998 & WHO-98 & & $0-57-1.9$ & & {$[25]$} \\
\hline Mackerel & & & & & $0.32-0.33$ & & \\
\hline Cod & & 1995-1997 & & & $0.04-0.05$ & & \\
\hline Plaice & & 1996-1998 & & & $0.29-0.36$ & & \\
\hline Salmon, farmed & Norway & 1997 & & & $0.35-0.50$ & & \\
\hline Mussel & Denmark & 1998 & & & 0.39 & & \\
\hline Herring & Grenland Fjords, Norway & $2000-2001$ & WHO-98 & 2.1 & 9.6 & 12 & {$[7]$} \\
\hline Mackerel & & & & 2.6 & 4.9 & 7.4 & \\
\hline Cod & & & & 0.67 & 0.85 & 1.5 & \\
\hline Eel & & & & $1.4-3.9$ & $5-23$ & $6.4-24$ & \\
\hline Shrimps & & & & 0.23 & 8.2 & 8.4 & \\
\hline Mussel & & & & $0.27-0.34$ & $1.3-2.6$ & $1.6-3.0$ & \\
\hline Eel & Amsterdam area, Netherlands & & DWG & & $1.9-71$ & & {$[26]$} \\
\hline Eel & Havel, Oder, Germany & 1996 & I-TEQ & $0-170^{\mathrm{b}}$ & $2-15^{\mathrm{b}}$ & & [27] \\
\hline Anchovy & Adriatic Sea, Italy & 1997-1998 & I-TEQ & & $0.23-0.47$ & & {$[28]$} \\
\hline Mussel & & & & & $0.11-0.24$ & & \\
\hline Mackerel & & & & & $0.59-1.1$ & & \\
\hline Prawns & Retail samples, Belgium & $2000-2001$ & WHO-98 & - & 0.65 & & {$[6]$} \\
\hline Mackerel & & & & & 6.2 & & \\
\hline Trout & & & & & 0.04 & & \\
\hline Salmon & Market fish, Spain & $2001-2003$ & WHO-98 & 0.975 .1 & $0.45-0.54$ & $1.4-5.6$ & {$[29]$} \\
\hline Sardines & & & & $1.7-2.1$ & $0.39-0.50$ & $2.1-2.6$ & \\
\hline Tuna & & & & $0.68-6.9$ & $0.01-0.66$ & $0.69-7.5$ & \\
\hline Oyster & & & & $0.16-0.98$ & $0.37-0.73$ & $0.53-1.7$ & \\
\hline Clams & & & & $0.01-0.38$ & $0.001-0.16$ & $0.01-0.54$ & \\
\hline Mussels & & & & $0.07-1.2$ & $0.05-0.15$ & $0.12-1.3$ & \\
\hline
\end{tabular}

$D W G$ Dutch working group

${ }^{\text {a }}$ See electronic supplementary material for the actual TEF values

${ }^{\mathrm{b}}$ On lipid weight basis

above the MRL of $4 \mathrm{pg} / \mathrm{g}$ ww. Dutch farmed eel and imported eel (also mainly consisting of farmed eel) showed lower $\mathrm{PCDD} / \mathrm{F}$ TEQ concentrations and were all below the EC MRL. The PCDD/F TEQ concentrations in this study correspond with data from 1991 [9]. A study on wild eel from the south coast of Norway showed PCDD/F concentrations of $0.4-2.7 \mathrm{pg} T E Q / \mathrm{g}$ ww, which are within the range of the PCDD/F TEQ concentrations in the current study [31].

\section{$D L-P C B s$ and indicator PCBs}

In all wild eel samples PCB TEQ values were much higher than $\mathrm{PCDD} / \mathrm{F}$ TEQ values, ranging from 0.7 to $44 \mathrm{pg}$ TEQ/g ww. A higher contribution of the DL-PCBs to the total TEQ was also observed for farmed and imported eel. Owing to the high DLPCB contamination, a large fraction $(53 \%)$ of the wild eel samples does not comply with the current EC MRL of $12 \mathrm{pg}$ TEQ/g ww (sum of DL-PCBs and PCDD/Fs). DL-PCB TEQ values in the study from the early 1990s were higher (by factor of 1.2-7.7) than those from the same locations in this study (data not shown) [9]. This is mainly explained by the downward trend of PCB concentrations [30]. However, the TEF values used at that time (originating from the DWG) resulted in approximately $10-20 \%$ lower TEQ values compared with the $\mathrm{TEF}_{\mathrm{WHO}} 1997$ (mainly due to a lower $\mathrm{TEF}_{\mathrm{DWG}}$ value for PCB 118). Non-ortho PCB TEQs in Norwegian south coast eel amounted to $0.8-3.6 \mathrm{pg} / \mathrm{g}$ ww, which is within the range of the current study [31]. 
Table 3 Ranges and medians (in parentheses) of dioxins, DL-PCBs (based on the WHO 1997 TEFs) and indicator PCBs in a wide range of eel samples

\begin{tabular}{|c|c|c|c|c|c|c|c|c|}
\hline Species & $\mathrm{n}$ & $\begin{array}{l}\text { Lipids } \\
(\%)\end{array}$ & Non-ortho PCBs & Mono-ortho PCBs & DL-PCBs & $\begin{array}{l}\mathrm{PCDD} / \mathrm{Fs} \\
\text { (pg TEQ/g ww) }\end{array}$ & $\mathrm{DL}-\mathrm{PCBs}+\mathrm{PCDD} / \mathrm{Fs}$ & $\begin{array}{l}\Sigma \mathrm{PCB}_{7}^{\mathrm{a}} \\
\text { (ng/g ww) }\end{array}$ \\
\hline EC MRL & - & - & - & - & - & 4 & 12 & - \\
\hline Wild & 39 & $3.7-23$ & $0.3-14(3.8)$ & $0.4-30(6.0)$ & $\begin{array}{c}0.7-44 \\
(10)\end{array}$ & $0.2-7.9(1.8)$ & $0.9-52(13)$ & $13-1,739$ (296) \\
\hline Farmed & 11 & $29-38$ & $1.2-6.1(3.9)$ & $0.6-2.0(1.3)$ & $\begin{array}{c}1.8-7.7 \\
(5.2)\end{array}$ & $0.8-3.3(2.2)$ & $2.6-11(7.6)$ & $18-70(45)$ \\
\hline Imported & 14 & $20-34$ & $0.3-5.2(1.5)$ & $0.1-1.8(0.7)$ & $\begin{array}{c}0.3-7.1 \\
(2.1)\end{array}$ & $0.2-2.9(0.9)$ & $0.5-9.8(3.2)$ & $\begin{array}{l}\text { LOQ to } 65 \\
\text { (23) }\end{array}$ \\
\hline
\end{tabular}

$L O Q$ limit of quantification

${ }^{\mathrm{a}}$ Sum of PCBs 28, 52, 101, 118, 138, 153 and 180

The highest indicator-PCB concentrations observed in this study (Table 3), ranging between 13 and $1739 \mathrm{ng} / \mathrm{g}$ ww, correspond to PCB concentrations (852-1,722 ng/g ww) observed in Finnish eel originating from lakes with a known PCB contamination due to presence of a paper mill upstream [8]. The wide range of concentrations in the current study is similar to the wide range observed in American eel from the Delaware River and coastal tributaries ( $\Sigma$ PCBs $80-1,600 \mathrm{ng} / \mathrm{g} \mathrm{ww}$ ), but is (much) lower than PCB concentrations observed in the Hudson River (1,800-7,730 ng/g ww) [32]. Swedish eel samples contained (on average) a $\Sigma \mathrm{PCB}_{7}$ concentration (sum of PCBs 28, 52, 101, 118, 138, 153 and 180) of $193 \mathrm{ng} / \mathrm{g} \mathrm{ww}$ for eel caught in the Baltic [5], which is below the median $\Sigma \mathrm{PCB}_{7}$ concentration in wild eel in the present study. The aforementioned downward $\mathrm{PCB}$ trend is confirmed by much lower $\Sigma \mathrm{PCB}_{7}$ concentrations compared with those found in the late 1970s [30].

Effect of smoking of eel on contaminant concentrations

An experiment was conducted in order to determine if smoking of eel would result in a reduction of contaminants. The results presented in Fig. 1 show that both traditional and industrial smoking influence the concentrations of contaminants in the eel. In the first experiment a concentration effect can be seen: as a result of decreasing moisture content due to the evaporation of water during the smoking process, the fat content and the concentrations of contaminants (on a wet weight basis) increased. The contaminant concentrations in the second experiment remained almost the same after smoking. The results, expressed as chemical mass (as determined by the weight of fish multiplied by the concentration of contaminants in the fillet), show a decrease of PCDD/F TEQ of $12-45 \%$ (data not shown) for all smoked samples compared with the raw material. This decrease corresponds to the PCBs reduction of $40 \%$ found by Zabik and Zabik [33] after smoking of Great Lakes lake trout fillets. A 2,3,7,8-TCDD reduction of $100 \%$ was determined in another study on smoking of Great Lakes lake trout [34]. It should be noted that in our study the chemical mass was calculated based on the weight of the whole fish multiplied by the concentration of contaminants in the fillet, whereas in the other studies the weight of the fillet only was multiplied by the concentration of contaminants in the fillet, which is more correct because it takes only the edible part into account.

Lower-chlorinated PCBs (up to CB-52) largely disappeared from the eel owing to volatilization. The concentrations were mostly below the limit of quantification (LOQ) after smoking (Fig. 2). To our knowledge, no other results on reduction of lower-chlorinated PCBs in fish by smoking have been reported.

\section{Contaminant profile information}

\section{Contribution of DL-PCBs to the total TEQ}

The contribution of PCBs and PCDD/Fs to the TEQ is shown in Fig. 3. In all samples (except shrimps), a prevalence of DL-PCBs (on a TEQ basis) is found, ranging from $53 \%$ for herring to $83 \%$ for tuna. This corresponds nicely to data reported by Focant et al. [6] but the prevalence is somewhat less than in Dutch fish from 1991 [9], which most likely is caused by the decrease of the (DL-) PCB concentrations since 1991. Eel show a high PCB contribution to the total TEQ, which is caused by the relatively high PCB contamination of the Dutch freshwater systems. In wild eel, DL-PCBs contributed $69-98 \%$ to the total TEQ (Table 3), and within the DL-PCBs, the monoortho PCBs generally predominate (contribution of 49$58 \%$ to the PCB TEQ), while in other fish the non-ortho PCBs predominate (average $80 \%$ ). This could be caused by the ability of eel to metabolize CB-77 and CB-126, leading to a lower non-ortho $\mathrm{PCB}$ contribution [9]. However, in farmed eel, the contribution of non-ortho PCBs to the $\mathrm{PCB}$ TEQ is predominant (67-86\%). This is presumably caused by a different contamination pattern of their feed (typically 
Fig. 1 Influence of smoking on the polychlorinated dibenzo- $p$ dioxins/dibenzofurans $(P C D D / F s)$, dioxin-like PCBs (DL-PCBs), total toxic equivalents $(T E Q)$ and lipid and moisture content in eel

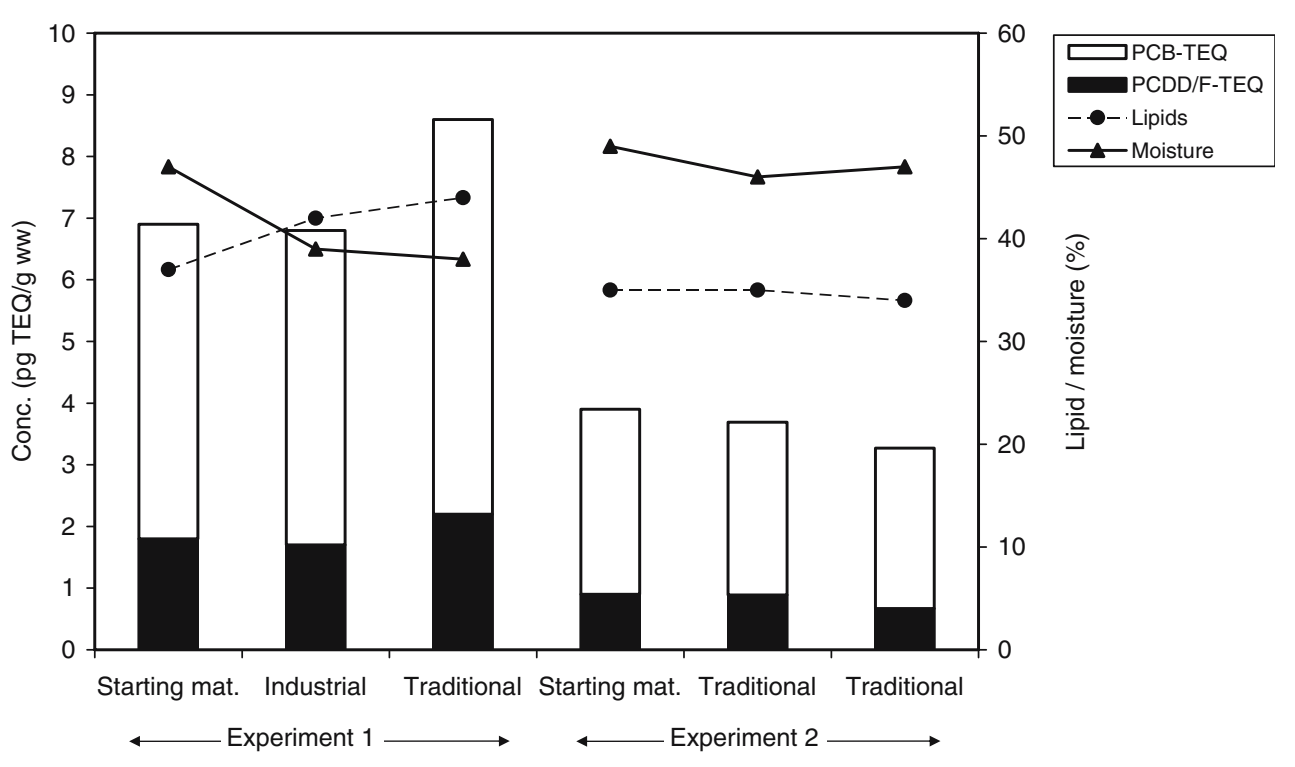

composed of feed with marine fish oil). Furthermore, farmed eel is less active than wild eel, which may influence their metabolic activity as well.

\section{Congener profile analysis}

A principal-component analysis (PCA) was carried out to investigate differences in congener profiles of marine fish, shellfish and farmed fish (salmon). The PCA was carried out for CB-77, CB-126, CB-169 and all PCDD/F congeners except those for which the majority of the samples were below the LOQ (1,2,3,7,8,9-hexachlorodibenzofuran and 1,2,3,4,7,8,9-heptachlorodibenzofuran). Furthermore, highly contaminated samples like eel and fish livers were removed from the dataset. The PCA plots are shown in Fig. 4. The profiles of four identified clusters are shown in Fig. 5.
The columns in the histograms are relative to the sum of the absolute (not multiplied with TEFs) concentrations of all compounds. The histograms concern averages of the clustered samples and standard deviations are indicated by bars. Concentrations below the LOQ were set at zero.

The four identified congener profiles are distinctive. Cluster 1 (fish from the Mediterranean, $n=3$ ) stands out from the other clusters as the fish contain relatively high concentrations of non-ortho PCBs (making up over $98 \%$ of the sum of the absolute concentrations, i.e. sum of the concentrations of PCDD/Fs and CB-77, CB-126, CB-169). Similar studies on Mediterranean fish confirm the relatively high non-ortho PCB concentrations $[4,28,35,36]$. The $\mathrm{PCDD} / \mathrm{F}$ profile from the present study is very similar to the profiles for Mediterranean fish given by Bayarri et al. [28], with 2,3,4,7,8-pentachlorodibenzofuran $(2,3,4,7,8$ -
Fig. 2 Loss of lower-chlorinated PCBs from the fillets as a result of smoking of eel. $L O Q$ limit of quantification

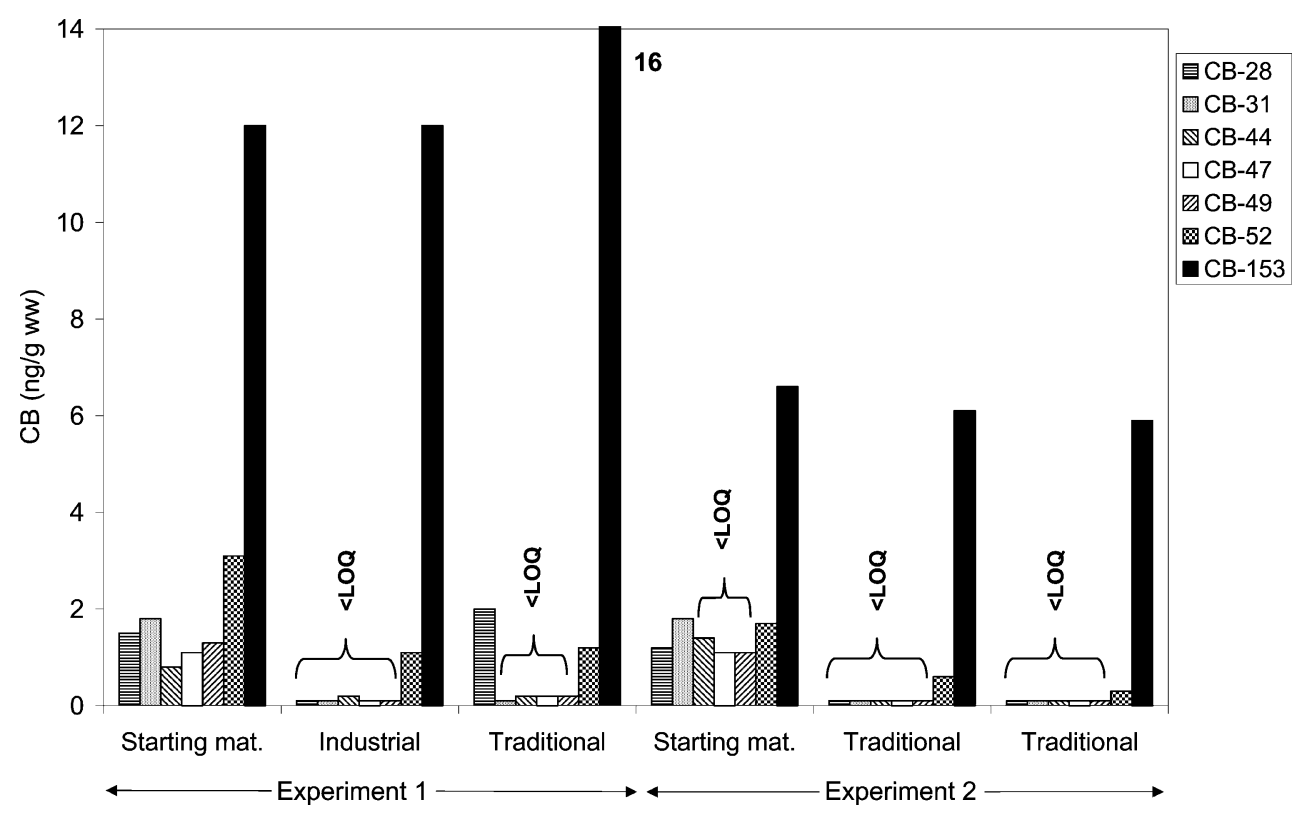


Fig. 3 Average contribution of PCDD/Fs and DL-PCBs to the total TEQ for various fish (caught in the year 2000) using the WHO 1997 toxic equivalency factors (TEFs). Bars represent the standard deviation of the average value



PeCDF) being the predominant congener, making up over $40 \%$ of the sum of PCDD/Fs. Together with $2,3,7,8-$ tetrachlorodibenzofuran (2,3,7,8-TCDF), 2,3,7,8-TCDD and $1,2,3,7,8$-PeCDD they make up nearly $80 \%$ of the sum of PCDD/Fs (present study). As no PCBs almost exclusively determine the total TEQ in Mediterranean fish, monitoring of these three PCBs could be sufficient for food-safety purposes. Cluster 2 concerns pikeperch, the profile of which is also dominated by the non-ortho PCBs ( $97 \%$ of the sum of PCDD/Fs and non-ortho PCBs). The enrichment of CB-77, found by de Boer et al. [9], was confirmed in the present study. Among the PCDD/Fs,
2,3,7,8-TCDD, 2,3,7,8-TCDF and octachlorodibenzo- $p$ dioxin (OCDD) dominate the profile. Cluster 3 shows one salmon and two mussel samples. The salmon sample within the mussel cluster could not be confirmed by the other three salmon samples. The low number of samples and a different origin probably explain these differences.

Concerning the mussel samples, non-ortho PCBs make up about $84 \%$ of the sum of PCDD/Fs and non-ortho PCBs. Within the group of PCDD/Fs, OCDD is the predominant congener, followed by 2,3,7,8-TCDD, 1,2,3,4,6,7,8-heptachlorodibenzofuran and octachlorodibenzofuran (OCDF). Burgess and McKinney [37] showed that the PCB profile

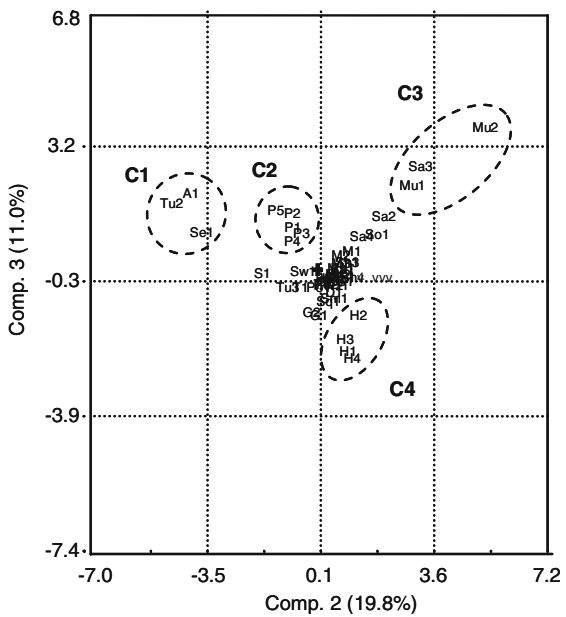

Fig. 4 Principal-component score and loading plot of PC2 and PC3 of fish samples from the year 2000. The circles represent the different fish groups and have no statistical significance. Abbreviations in the left plot concern fish type and order number (e.g. Mu2 = mussel sample 2). $C 1$ Mediterranean fish $(\mathrm{A}=$ anchovy; $\mathrm{Se}=\mathrm{Sea}$ bass; $\mathrm{Tu}=$ tuna $), C 2$ pike perch $(\mathrm{P}=$ pike perch), $C 3$ mussel $(\mathrm{Mu}=$ mussel; $\mathrm{Sa}=$ salmon $), C 4$ herring $(\mathrm{H}=$ herring). 2,3,7,8-TCDF 2,3,7,8-tetrachlorodibenzofuran, 1,2,3,7,8-PeCDF 1,2,3,7,8-pentachlorodibenzofuran, 2,3,4,7,8-PeCDF 2,3,4,7,8-pentachloro-

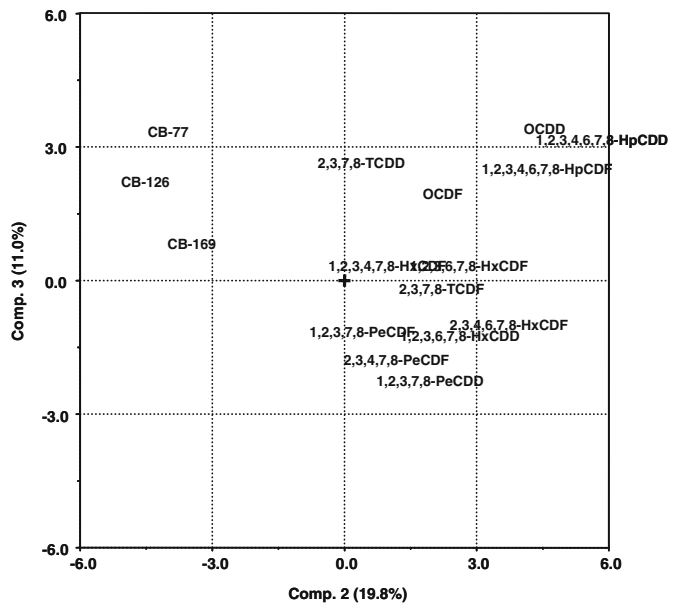

dibenzofuran, 1,2,3,4,7,8-HxCDF 1,2,3,4,7,8-hexachlorodibenzofuran, 1,2,3,6,7,8-HxCDF 1,2,3,6,7,8-hexachlorodibenzofuran, 2,3,4,6,7,8-HxCDF 2,3,4,6,7,8-hexachlorodibenzofuran, 1,2,3,4,6,7,8-HpCDF 1,2,3,4,6,7,8-heptachlorodibenzofuran, 1,2,3,4,7,8,9-HpCDF, $O C D F$ octachlorodibenzofuran, 2,3,7,8-TCDD 2,3,7,8-tetrachlorodibenzo-p-dioxin, 1,2,3,7,8-PeCDD 1,2,3,7,8-pentachlorodibenzo- $p$-dioxin, 1,2,3,6,7,8-HxCDD 1,2,3,3,7,8-hexachlorodibenzo-p-dioxin, 1,2,3,4,6,7,8-HpCDD 1,2,3,4,6,7,8-heptachlorodibenzofuran, $O C D D$ octachlorodibenzo- $p$-dioxin 


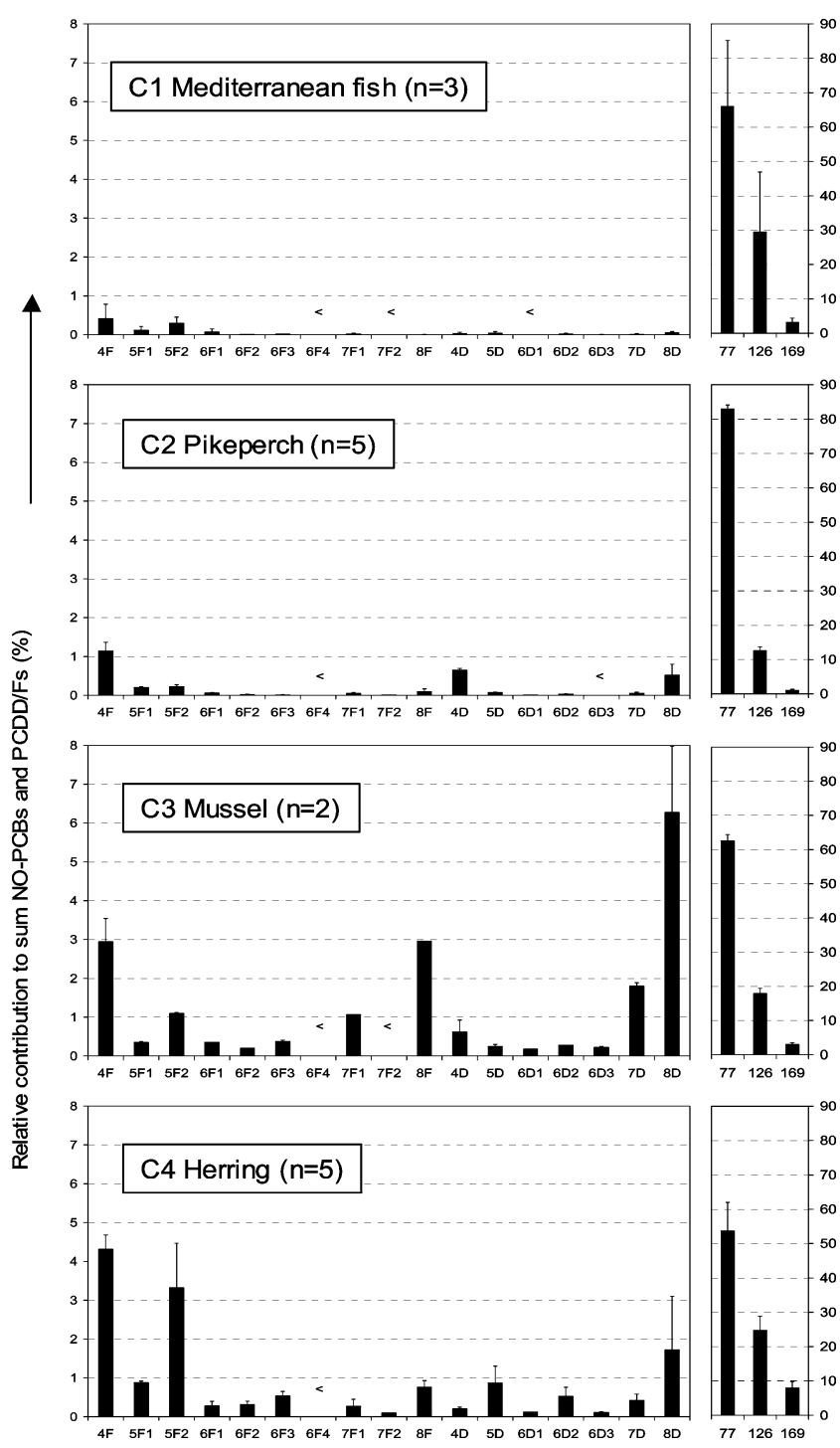

Fig. 5 Congener profile information of pikeperch, salmon, mussels, herring and Mediterranean fish, relative to the sum of PCDD/F and non-ortho $\mathrm{PCB}$ concentrations. $<$ indicates that this congener was below the LOQ in all samples. $4 F$ 2,3,7,8-TCDF, 5F1 1,2,3,7,8PeCDF, 5F2 2,3,4,7,8-PeCDF, 6F1 1,2,3,4,7,8-HxCDF, $6 F 2$ 1,2,3,6,7,8-HxCDF, $6 F 3$ 2,3,4,6,7,8-HxCDF, $6 F 4$ 1,2,3,7,8,9-HxCDF, $7 F 1 \quad 1,2,3,4,6,7,8-\mathrm{HpCDF}, 7 F 21,2,3,4,7,8,9-\mathrm{HpCDF}, 8 F$ OCDF, $4 D$ 2,3,7,8-TCDD, $5 D$ 1,2,3,7,8-PeCDD, $6 D 1$ 1,2,3,4,7,8-HxCDD, $6 D 2$ $1,2,3,6,7,8-H x C D D, 6 D 3 \quad 1,2,3,7,8,9-H x C D D, 7 D \quad 1,2,3,4,6,7,8-$ HpCDD, 8D OCDD, 77 CB-77, 126 CB-126, 169 CB-169

in the tissue of a filter-feeding marine bivalve species (Mulinia lateralis) is very similar to the profile observed in the sediment and overlying water. This suggests that the profile observed in our samples is caused by the profile in the sediment and particulate matter at the harvest location of the mussels, although there are no data available to confirm this. The profile reported by Gomara et al. [29] on mussel samples from the Spanish market were very similar to our data. Bayarri et al. [28] reported a different pattern $(2,3,4,7,8$ $\mathrm{PeCDF}$ and $2,3,7,8$-TCDF as almost the only $\mathrm{PCDD} / \mathrm{F}$ congeners present) in mussels from the Adriatic Sea, which is characteristic for that location as was also observed in other fish. Concerning the herring cluster (cluster 4), the predominance of 2,3,7,8-TCDF, 2,3,4,7,8-PeCDF and $1,2,3,7,8-\mathrm{PeCDD}$ determines the deviating profile compared with that for other fish from the English Channel and the North Sea. Different feeding habits (and therefore bioaccumulation) and a stronger migration pattern from those of other species could be the cause for these deviating profiles. The PCDD/F profile in herring from the present study was similar to the profile of herring and herring products from northwest Europe (including the Baltic Sea [25]). A food web study of Baltic herring showed that the contamination profile for PCBs was similar to the profile in the diet of herring (mysis and zooplankton) [38]. It is likely that the North Sea herring contamination profile is also dictated by the diet, but contamination data of the diet were not available at the time of writing.

\section{Evaluation of new TEFs}

Following revision of the $\mathrm{TEF}_{\mathrm{WHO}} 1997$ values, the WHO accepted new human TEFs $[23,39]$ in $2006\left(\mathrm{TEF}_{\mathrm{WHO}} 2006\right)$. The changes comprise $(1997 \rightarrow 2006)$ TEFs for $1,2,3,7,8$ PeCDF $(0.05 \rightarrow 0.03), 2,3,4,7,8-\mathrm{PeCDF}(0.5 \rightarrow 0.3)$, OCDD $(0.0001 \rightarrow 0.0003)$, OCDF $(0.0001 \rightarrow 0.0003)$, CB-81 $(0.0001 \rightarrow 0.0003)$ and CB-169 $(0.01 \rightarrow 0.03)$, and finally the TEFs for all mono-ortho PCBs are lowered to 0.00003 (except that for CB-167, which was increased from 0.00001 to 0.00003 ).

Table 4 shows that the application of $\mathrm{TEF}_{\mathrm{WHO}} 2006$ values results in a slight increase of the non-ortho PCB TEQ, mainly resulting from an increased CB-169 contribution. However, the mono-ortho PCB contribution to the TEQ dramatically decreased by $70-80 \%$, largely caused by a combination of the reduced CB-156 and CB-118 TEFs and the relatively high concentrations of these congeners in fish samples. The reduction of the PCDD/F TEQs is mainly a result of the reduced 2,3,4,7,8-PeCDF TEF. The total TEQ reduction caused by use of the new TEFs is in the range 10 $20 \%$. Wild eel is the exception to this, owing to the relatively high level of mono-ortho PCBs with an average reduction of the total TEQ of $43 \%$. The current EC MRLs, based on $\mathrm{TEF}_{\mathrm{WHO}} 1997$ would result in $51 \%$ of the eel samples not complying with the MRL. Using the $\mathrm{TEF}_{\mathrm{WHO}} 2006$, noncompliance is reduced to $28 \%$. It should be noted that, for the coming years, the new WHO TEFs will probably not be implemented in the EC MRL calculation.

Screening samples using the DR CALUX ${ }^{\circledR}$ assay

The DR CALUX ${ }^{\circledR}[10]$ assay was used to estimate the total TEQ levels and in particular to select samples requiring 
Table 4 Average concentrations of PCDD/Fs and DL-PCBs calculated with WHO 2006 TEFs

\begin{tabular}{|c|c|c|c|c|c|c|c|}
\hline Species & Origin & $n$ & Non-ortho PCBs & Mono-ortho PCBs & $\begin{array}{l}\text { DL-PCBs } \\
\text { (pg TEQ/g ww) }\end{array}$ & $\mathrm{PCDD} / \mathrm{Fs}$ & $\mathrm{DL}-\mathrm{PCBs}+\mathrm{PCDD} / \mathrm{Fs}$ \\
\hline EC MRL & - & - & - & - & - & 4 & 8 (12 for eel) \\
\hline Cod & North Sea & 2 & $0.3(104)$ & $0.01(22)$ & $0.3(89)$ & $0.2(95)$ & $0.5(91)$ \\
\hline Wild eel & Dutch freshwater systems & 39 & $5.1(105)$ & $1.7(20)$ & $6.8(51)$ & $2.0(90)$ & $8.9(57)$ \\
\hline Farmed eel & Various Dutch farmers & 11 & $4.1(103)$ & $0.3(22)$ & $4.4(84)$ & $1.6(77)$ & $5.9(82)$ \\
\hline Herring & English Channel, North Sea & 4 & $1.4(106)$ & $0.1(24)$ & $1.5(89)$ & $1.3(80)$ & $2.8(85)$ \\
\hline Salmon & Norway, Scotland & 4 & $2.2(104)$ & $0.2(30)$ & $2.3(90)$ & $1.1(84)$ & $3.4(88)$ \\
\hline
\end{tabular}

A selection of fish samples is taken from Tables 1 and 3

The relative 1997 TEF concentrations (percent) compared with the 2006 TEFs concentrations are given in the parentheses

further analysis by GC-HRMS. Considering the high concentrations of mono-ortho PCBs in eel samples and the relatively poor response of these PCBs in the assay, concentrations were estimated by comparison with a set of fish oil samples spiked with PCDD/Fs, non-ortho PCBs and mono-ortho PCBs in a representative composition of 15:40:45 in terms of the contribution to the TEQ level. The dioxin mixture used for spiking contained equal amounts of all congeners, the non-ortho PCB mix contained equal amounts of PCBs 77, 126 and 169, and the mono-ortho PCB mix contained PCBs 118 and 156 in a composition of 7:1. On the basis of $\mathrm{TEF}_{\mathrm{WHO}} 1997$ the levels in oil were 200, 120, 60, 30 and $0 \mathrm{pg} \mathrm{TEQ} / \mathrm{g}$. With $\mathrm{TEF}_{\mathrm{WHO}}$ 2006, concentrations were $30 \%$ lower. Samples that were below the DR CALUX ${ }^{\circledR}$ assay LOQ (10 pg TEQ/g lipid weight) were removed from the dataset (13\% of the datapoints; Fig. 6), because the DR CALUX ${ }^{\circledR}$ assay sensitivity was not optimized for the very low concentrations at the time of the study. A further improvement in sensitivity was obtained by dissolving the extract in a smaller amount of DMSO [10]. Figure 6 compares the levels based on both TEF systems, showing a good relation between the DR CALUX ${ }^{\circledR}$ assay and GC-HRMS with an almost 1:1 relationship for $\mathrm{TEF}_{\mathrm{WHO} 1997 .}$ On the basis of $\mathrm{TEF}_{\mathrm{WHO} 2006}$ the correlation has improved $\left(R^{2}=0.91\right)$, but in this case the DR-CALUX ${ }^{\circledR}$ assay overestimated the levels 1.4 -fold. This was somewhat unexpected since the new TEF values are much closer to the resulting relative potency values $[10,40]$ in the bioassay. Although this was overcome by the use of reference samples, a better correlation was particularly expected (using the new TEFs) for samples with a composition deviating from that of the reference samples. The intercept of the regression line almost goes through the origin (intercept 0.2), meaning that the use of $\mathrm{TEF}_{\mathrm{WHO}} 2006$ results in an improved relation of the data in the lower parts of the curve. One explanation for the overestimation (1.4-fold) by the bioassay may be that
Fig. 6 Comparison of totalTEQ results obtained by gas chromatography-high-resolution mass spectrometry (GC-HRMS) and DR CALUX ${ }^{\circledR}$ assay. GCHRMS results were calculated using two different TEF systems (1997 and 2006). Lower-bound results are shown for GC-HRMS and DR CALUX ${ }^{\circledR}$ assay data below the LOQ (10 pg TEQ/g lipids) excluded

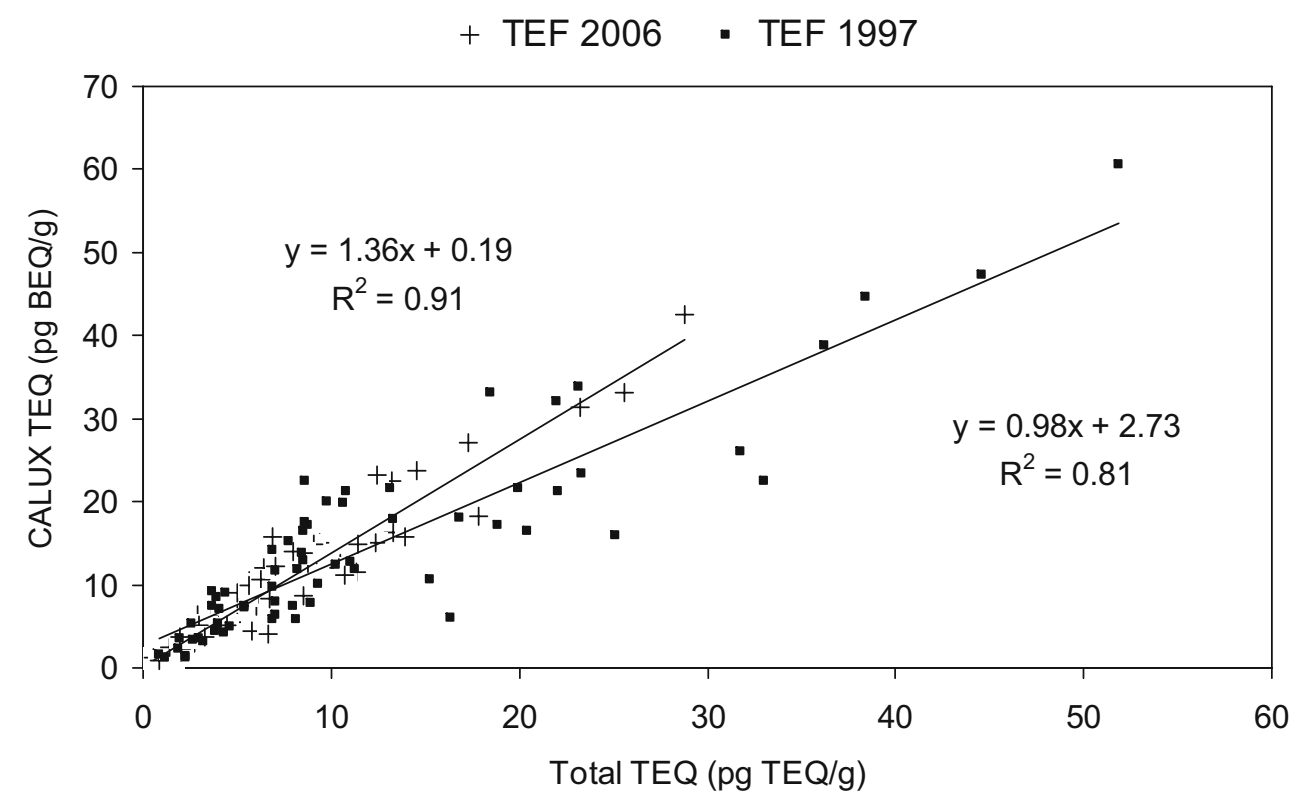


the DR CALUX ${ }^{\circledR}$ assay actually detects other dioxin-like compounds present in eel. Several contaminants (such as polybrominated diphenyl ethers) have shown agonistic or antagonistic behaviour [41, 42], which may have influenced the signal in the DR CALUX ${ }^{\circledR}$ assay. However, this requires further investigation.

Implications for eel consumption

The high PCDD/F and PCB concentrations found in eel may pose a risk to consumers in the case of preference consumption. In order to determine this, we calculated the amount of eel that safely could be eaten without exceeding the tolerable weekly intake (TWI) of $14 \mathrm{pg}$ total TEQ/ $/ \mathrm{kg}$ body weight as set by the EC Scientific Committee for Food (SCF) [43]. Baars et al. [44] determined a life-long average intake of $1.2 \mathrm{pg}$ total TEQ/kg body weight/day (median). As a result, the average Dutch TEQ intake is $5.6 \mathrm{pg} / \mathrm{kg}$ body weight/week below the TWI of 14 . With a median eel total TEQ of $13 \mathrm{pg} T E Q / \mathrm{g}$ ww, the average consumer is allowed to consume only $28 \mathrm{~g}$ of the median contaminated eel per week (life-long). The consumption of the most contaminated eel (52 pg total TEQ/g ww) drops down to $7 \mathrm{~g} /$ week (life-long). Although this is a very small amount, and regular portion sizes are on the order of 100-200 g, the average consumption of eel in the Netherlands is only $0.9 \mathrm{~g} /$ week [45]. Therefore, the average Dutch consumer will presumably not be at risk when consuming Dutch wild eel, even from the most polluted sites. Only a small group of frequent consumers such as sports anglers, professional fishermen and consumers preferring wild eel may be at risk when frequently consuming the most contaminated eels.

\section{Conclusions}

This study reveals that nearly all fish from Dutch markets currently meet the EC MRL for PCDD/Fs and total TEQ. Total TEQ values are generally below $8 \mathrm{pg} \mathrm{TEQ} / \mathrm{g}$ ww, with the exception of those for tuna and sea bass from the Mediterranean and anchovy. Furthermore, eel from the main Dutch river systems Rhine and Meuse are highly polluted with PCBs (including DL-PCBs) up to total TEQ concentrations of $52 \mathrm{pg} \mathrm{TEQ} / \mathrm{g}$ ww. Fifty-three percent of the 39 wild eel samples exceeded the current the EC MRL of $12 \mathrm{pg}$ total TEQ/g ww.

Smoking of eel does not lead to significant PCDD/F or PCB TEQ reduction (on a wet weight basis). Consequently, smoking is not a suitable option for reduction of PCB and $\mathrm{PCDD} / \mathrm{F}$ concentrations in eel. Only some reduction of PCBs may be obtained from the volatilization of some lower-chlorinated PCBs.
The DL-PCBs were the predominant contributors to the total TEQ in all fish and shellfish species, except in shrimps. The DL-PCB contribution rises (on average) from $53 \%$ in herring to $83 \%$ in tuna. Distinctive differences in congener profiles of $\mathrm{PCDD} / \mathrm{Fs}$ and non-ortho $\mathrm{PCBs}$ in mussels, Mediterranean fish, herring and pikeperch could be explained by differences in metabolism, feeding habits, location and migration.

The new WHO TEFs lead to a decrease of $10-20 \%$ of the total TEQ, compared with the WHO TEF values from 1997. Owing to the relatively high mono-ortho PCB concentrations in wild eel, the reduction in the total TEQ in eel due to the new TEFs is relatively strong (about 40\%) in this species.

For screening eel samples, the DR CALUX ${ }^{\circledR}$ assay is suitable if combined with GC-HRMS for confirmation of positive samples. Application of the new TEFs results in a 1.4-fold overestimation compared with GC-HRMS.

Acknowledgements The Dutch Ministry of Agriculture, Nature and Food Quality is acknowledged for its financial support of this project. Colleagues at IMARES, IJmuiden, The Netherlands, are acknowledged for their skillful determination of lipid and PCB contents (M. Lohman, Q. Dao) and fish sampling (E. v. Barneveld and K. Groeneveld) within this project.

\section{References}

1. EC (2001) Council regulation (EC) no 2375/2001, 29 November 2001

2. EC (2006) Council regulation (EC) no 199/2006, 3 February 2006

3. SCOOP (2000) Assessment of dietary intake of dioxins and related PCBs by the population of EU member states. DirectorateGeneral Health and Consumer Protection, European Commission Brussels

4. Abad E, Abalos M, Calvo M, Nombela J, Caixach J, Rivera J (2003) Organohalogen Compd 62:49-52

5. Atuma SS, Linder CE, Wicklund-Glynn A, Andersson O, Larsson L (1996) Chemosphere 33:791-799

6. Focant JF, Eppe G, Pirard C, Massart AC, Andre JE, De Pauw E (2002) Chemosphere 48:167-179

7. Knutzen J, Bjerkeng B, Naes K, Schlabach M (2003) Chemosphere 52:745-760

8. Tulonen J, Vuorinen PJ (1996) Sci Total Environ 187:11-18

9. de Boer J, Stronck CJN, Traag WA, van der Meer J (1993) Chemosphere 26:1823-1842

10. Hoogenboom L, Goeyens L, Carbonnelle S, Van Loco J, Beernaert H, Baeyens W, Traag W, Bovee T, Jacobs G, Schoeters G (2006) Trends Anal Chem 25:410-420

11. van Ginneken VJT, Maes GE (2005) Rev Fish Biol Fish 15:367-398

12. Durif C, Dufour S, Elie P (2005) J Fish Biol 66:1025-1043

13. Van den Berg M, Birbaum L, Bosveld ATC, Brunström B, Cook P, Feeley M, Giesy JP, Hanberg A, Hasegava R, Kennedy SW, Kubiak T, Larsen JCh, van Leeuwen FXR, Liem AKD, Nolt C, Peterson RE, Poellinger L, Safe S, Schrenk D, Tillitt D, Tysklind M, Younes M, Waern F, Zacharewski T (1998) Environ Health Perspect 106:775-792 
14. de Boer J (1988) Chemosphere 17:1803-1810

15. Tuinstra LGMT, Traag WA, Van Rhijn JA, Van der Spreng PF (1994) Chemosphere 29:1859-1875

16. Ballschmiter K, Bacher R, Mennel A, Fischer R, Reehle U, Swerev M (1992) J High Resolut Chromatogr 15:260-270

17. Bovee TFH, Hoogenboom LAP, Hamers ARM, Traag WA, Zuidema T, Aarts J, Brouwer A, Kuiper HA (1998) Food Addit Contam 15:863-875

18. QUASIMEME (2007) QUASIMEME. http://www.quasimeme.org. Cited 8 Mar 2007

19. Folkehelsa (2007) http://www.fhi.no - for et friskere folk. http:// www.fhi.no. Cited 8 Mar 2007

20. DIFFERENCE (2007) Dioxins.nl development of alternative methods for laboratory dioxin analysis in the EU projects DIAC and DIFFERENCE. http://www.dioxins.nl. Cited 8 Mar 2007

21. Gizzi G, Hoogenboom LAP, von Holst C, Rose M, Anklam E (2005) Food Addit Contam 22:472-481

22. Van Loco J, van Leeuwen SPJ, Roos P, Carbonnelle S, de Boer J, Goeyens L, Beernaert H (2004) Talanta 63:1169-1182

23. van den Berg M, Birnbaum LS, Denison M, De Vito M, Farland W, Feeley M, Fiedler H, Hakansson H, Hanberg A, Haws L, Rose M, Safe S, Schrenk D, Tohyama C, Tritscher A, Tuomisto J, Tysklind M, Walker N, Peterson RE (2006) Toxicol Sci 93:223-241

24. Parmanne R, Hallikainen A, Isosaari P, Kiviranta H, Koistinen J, Laine O, Rantakokko P, Vuorinen PJ, Vartiainen T (2006) Mar Pollut Bull 52:149-161

25. Karl H, Ruoff U, Bluthgen A (2002) Chemosphere 49:765-773

26. van der Oost R, Opperhuizen A, Satumalay K, Heida H, Vermeulen NPE (1996) Aquat Toxicol 35:21-46

27. Wiesmuller T, Schlatterer B (1999) Chemosphere 38:325-334

28. Bayarri S, Baldassarri LT, Iacovella N, Ferrara F, di Domenico A (2001) Chemosphere 43:601-610

29. Gomara B, Bordajandi LR, Fernandez MA, Herrero L, Abad E, Abalos M, Rivera J, Gonzalez MJ (2005) J Agric Food Chem 53:8406-8413
30. Pieters H, van Leeuwen SPJ, de Boer J (2004) Verontreinigingen in aal en snoekbaars: monitorprogramma ten behoeve van de Nederlandse sportvisserij 2003. Report C063/04. RIVO, IJmuiden

31. Hove H, Julshamn K, Haldorsen AKL (2003) Organohalogen Compd 62:204-206

32. Ashley JTF, Horwitz R, Steinbacher JC, Ruppel B (2003) Mar Pollut Bull 46:1294-1308

33. Zabik ME, Booren A, Zabik MJ, Welch R, Humphrey H (1996) Food Chem 55:231-239

34. Zabik ME, Zabik MJ (1995) Bull Environ Contam Toxicol 55: 264-269

35. Kannan K, Corsolini S, Imagawa T, Focardi S, Giesy JP (2001) Organohalogen Compd 52:374-377

36. Kannan K, Corsolini S, Imagawa T, Focardi S, Giesy JP (2002) Ambio 31:207-211

37. Burgess RM, McKinney RA (1999) Environ Pollut 104:373-382

38. Strandberg B (1998) Sci Total Environ 217:143-151

39. Word Health Organization (2007) WHO/World Health Organization. http://www.who.org. Cited 8 Mar 2007

40. Carbonnelle S, Van Loco J, Van Overmeire I, Windal I, Van Wouwe N, van Leeuwen S, Goeyens L (2004) Talanta 63:1255-1259

41. Peters AK, van Londen K, Bergman A, Bohonowych J, Denison MS, Van den Berg M, Sanderson JT (2004) Toxicol Sci 82:488-496

42. Chen GS, Bunce NJ (2003) Toxicol Sci 76:310-320

43. EC-SCF (2001) Scientific Committee on Food, Opinion of the Scientific Committee on Food on the risk assessment of dioxins dioxin-like PCBs in food. Adopted on 30 May 2001. http://ec. europa.eu/food/fs/sc/scf/out90 en.pdf. Cited 8 Mar 2007

44. Baars AJ, Bakker MI, Baumann RA, Boon PE, Freijer JI, Hoogenboom LAP, Hoogerbrugge R, van Klaveren JD, Liem AKD, Traag WA, de Vries J (2004) Toxicol Lett 151:51-61

45. Hoogenboom LAP, van Klaveren JD, Baars AJ, van Leeuwen FXR, Hoogerbrugge R, van Leeuwen SPJ, de Boer J (2001) Scenario studies on maximum levels for dioxins, dibenzofurans and dioxinlike PCBs in fish. Report 639102023. RIVM, Bilthoven 